\title{
The Right to Clean Environment: Lessons from India and Tanzania
}

\author{
By Emmanuel Opoku Awuku
}

\section{Introduction}

In today's world, society is becoming more and more conscious of the tremendous environmental damage caused to our planet. Every day we hear news about rainforest depletion, trees dying because of acid rain, toxins present in our lakes and water supplies, the continuous extermination of our wild life from the earth. Disasters, such as the explosion at the American multinational company "Union Carbide" in India, which ended over 2,500 lives, not counting those who suffered injuries and displacement, the Exxon Valdez disaster, the Chernobyl nuclear plant disaster in the former Soviet Union, cause serious damages to our environment. All these incidences have cost a lot of lives, created chronic diseases, atmospheric and water pollution, soil degradation, dying forests, and causes displacement of communities creating environmental refugees.

Despite growing awareness about environmental problems, governmental development programmes from both the North and the South still continue to cause serious environmental problems. An example is the James Bay hydroelectric project in Quebec, which has released mercury into the water, rendering fish unsafe to eat, threatening the lives of those living in the surrounding communities. Nearly half of the population of the native Cree and Inuit have suffered from contamination. In Ghana, the hydropower development in the Volta river basin has caused 70,000 cases of river blindness and forced the local people to flee the area. ${ }^{1}$

All these problems create environmental refugees, that is, people who have been forced from their traditional habitat, temporarily or permanently, because of marked environmental disruption (natural or triggered by people) that jeopardize their existence or seriously affect the quality of their life. ${ }^{2}$ Huge projects for improving the infrastructure and energy supply of a country, for which many people have to be resettled, often cause those people big material and non-material damage and endanger the environment.

1 See: Commission on Human Rights, Sub-Commission on Prevention of Discrimination and Protection of Minorities, Forty-Fourth Agenda Item 4: EMC.

2 S.T. Helin /W. Helin, Migration and the Environment: Interrelationships in Sub-Saharan Africa, Field Staff Reports. Universities Field Staff International, Sausalito 1993, p. 10. 
Demands have been expressed that the international financial institutes which provide the financial means for projects of that kind attach conditionalities to their credits which ensure that the humanitarian aspects, including environmental issues, are not neglected.

Apart from attaching conditions to financial support, more and more national legislation is appearing in the field of environmental law. But there are many examples that provide evidence that the legal framework is inadequate to deal with ecological disasters and other environmental problems. Many environmentalists are therefore arguing that legislation is not enough, that true guarantees of environmental protection will only come when society extends the concept of 'rights' to the environment. ${ }^{3}$ Only when the personal entitlement to a clean environment is successfully placed in the category of 'rights' can it be preserved from the day-to-day political process. In that way, the domestic political decisions will be significantly limited, which is very important "particularly given the high short-term costs involved in many environmental protection measures and the resulting political disfavour". 4

Shelton ${ }^{5}$ pointed out various views and alternatives. Firstly, environmental problems may be combated through the assertion of existing human rights such as the right to life, personal security, health, and food. In this regard, a safe and healthy environment may be viewed as a precondition to the exercise of existing rights. A second, intermediate position proposes a set of environmental rights based upon existing rights to information. The third position is that a specific right to a clean environment could be formulated and added to the current catalogue of human rights. These three positions suggest that environmental issues belong within the category of human rights. However, some argue that human beings are only one element of the ecosystem, and that it is necessary to protect nature as a whole, including animals and plants. So, clearly, human rights and environmental protection are different, but overlapping societal values. ${ }^{6}$

Environmental problems are especially pressing in developing countries. The shortage of basic necessities, such as shelter and clean drinking water, disease, poverty, and the need to feed and employ growing numbers of people is considered by many LDC's as much more urgent than environmental problems, in particular pollution, is seen by many LDC's as evidence of industrial development. They therefore see efforts to control pollution as

See: C. Giagnocavo / H. Goldstein, Law Reform or World Reform: The Problem of Environmental Rights, McGill Law Journal, Vol. 35, 1990, p. 345.

4 D. Shelton, Human Rights, environmental Rights, and the Right to Environment, Stanford Journal of International Law, Vol. 28, 1991, p. 107.

5 supra note 4 .

6 Ibid, pp. 104-105. 
efforts to constrain development. Others, however, think that one might learn from the environmental mistakes of the industrialized world.

Whereas environmentalists in the past had questioned and rejected the growth ethic, a change of emphasis in recent years looked at the links between environment and development. With the concept of 'sustainable development', economic growth and environment are no longer seen as incompatible. There is now agreement that the aims of the two can be assimilated to create a sustainable society. Sustainable development can be defined as "development that occurs within the carrying capacity of the natural and human environment" $"$. The term is usually applied to LDC's and the kind of economic and social development needed to improve living conditions of the poor countries in the world without destroying the natural resource base. But the concept is equally applicable to more developed countries.

It is in this light that this essay aims to investigate the problems relating to clean environment. How is the right to a clean environment implemented in national constitutions, what lessons can be learned from the Indian and Tanzanian constitutions, and what can other states draw from it?

\section{The international recognition of the right to a clean environment}

In this chapter, we will examine the international recognition of the right to a clean environment, and evaluate the content and character of legal obligations concerning the right to a clean environment. With the environmental problems mounting, the international community has become aware of the danger of the destruction of the planed, and thus started formulating rules and regulations on environmental protection.

The state of the environment is clearly linked to economic as well as social rights, such as access to food, shelter, health care and education. Economic rights recognize that all economic activities have a common and indivisible resources' base on environment, air, water, soil, vegetation and the seas. All these resources can be sustained when they are well managed, and they must be sustained for they are essentials of human life and development on our planet. ${ }^{8}$ So, if states are claiming the right to development, then there is the need for them to safeguard the environment, conserve the natural resources and plan their utilization according to their availability, both nationally and internationally.

8 Rights and Humanity, Celebrating the Universal Declaration of Human Rights and the Achievements of the United Nations, London 1989, p. 28. 
The United Nations have in their Charter reaffirmed their faith in fundamental human rights, in the dignity and worth of the human person and in the equal rights of men and women, and are determined to promote social progress and better standards of life in larger freedom. Article 12 of the International Convenant on Economic, Social and Cultural Rights of 1966 recognizes "the right of everyone to the enjoyment of the attainable standard of physical and mental health". It imposes on states correlative duties including the obligation to take the necessary steps for the improvement of all aspects of environmental hygiene. ${ }^{9}$

There have been many efforts in recent years from the international community and from non-governmental organizations to promote the right to a clean environment, the right to sustainable development. The United Nations Conference on the Human Environment was the first occasion when political, social and economic problems of the global environment were discussed at an intergovernmental level. The Conference took place in Stockholm, Sweden, from 5 June to 16 June 1972, and was attended by the representatives of 113 countries, 19 intergovernmental agencies, and 400 other intergovernmental and nongovernmental organizations. The aim of the Conference was to create a basis within the United Nations on which problems of the human environment could be comprehensively considered, and to draw the attention of governments and public opinion to the importance of the problem. ${ }^{10}$

The Conference produced a Declaration, a list of Principles and an Action Plan. The Declaration was intended to outline broad goals and objectives without making legally binding provisions. It proclaimed that man is both creature and moulder of his environment. A stage has been reached when, through the rapid acceleration of science and technology, man has acquired the power to transform his environment in countless ways and on an unprecedented scale. Both aspects of man's environment, the natural and the manmade, are essential to his well-being and to the enjoyment of basic human rights. ${ }^{11}$

The 26 Principles were concerned with five broad issues. They stated that:

(a) natural resources should be safeguarded and conserved, the earth's capacity to produce renewable resources should be maintained, and non-renewable resources should be shared,

9 Ian Brownlie (ed.), Basic Documents in International Law: International Convenants on Human Rights, Oxford 1983, p. 264.

10 Declaration of the United Nations Conference on Human Environment, Principle 2, U.N. Doc. A/Conf.48/14 rev. 1.

11 John McCormick, supra note 7. 
(b) development and environmental concern should go together, and less developed countries should be given every assistance and incentive to promote rational environmental management,

(c) each country should establish its own standards of environmental management and exploit resources as they wished but should not endanger other states, there should be international cooperation aimed at improving the environment,

(d) pollution should not exceed the capacity of the environment to clean itself, and oceanic pollution should be prevented,

(e) science, technology, education, and research should all be used to promote environmental protection. ${ }^{12}$

The Action Plan provided recommendations for internationally coordinated activities aimed at increasing knowledge about environmental issues, and at protecting and improving the quality of the environment.

A major result of the Conference was that it forced a compromise between the developed countries and the LDC's, in that the need to find a balance between environmental management priorities and the aims of economic development was recognized. A direct result of the Conference was also the creation of the United Nations Environment Programme (UNEP) which was to ensure that the principles were turned into policies and active programmes. Despite its handicaps, no executive power, limited funding and immensity of task, the UNEP has helped to raise the general level of environmental awareness with regard to both national and global environmental problems.

The African Charter on Human and Peoples Rights, which was ratified in 1986 by the majority of states from the Organization of African Unity and certain non-governmental organizations, also called for the right to a clean environment. Article 24 of the Charter states that "all people shall have the right to a general satisfactory environment favourable to their development". ${ }^{13}$ In Africa, the environment is a central issue, because most African states are industrially not developed and depend to a large extent on the exploitation of their natural resources.

The ASEAN states have also recognized environmental rights. In the ASEAN Agreement on Conservation of Nature and Natural Resources, Article 16, contracting parties are required to circulate, as wide as possible, information on conservation measures and their relationship with sustainable development objectives, The parties have a duty to organize

Ibid.

13 Human Rights: The African Charter on Human and Peoples Rights, Article 24, New York: The United Nations, p. 11. 
the participation of the public in the planning and implementation of conservation measures, which are considered fundamental to environmental protection. ${ }^{14}$

Article II of the Organization of American States' Additional Protocol to the American Convention on Human Rights in the Areas of Economic, Social and Cultural Rights of 1988 states that "everyone shall have the right to live in a healthy environment". It imposes correlative duties on states. State parties shall promote the protection, preservation, and improvement of the environment. ${ }^{15}$

The 1989 Hague Declaration on the Environment provides the right to live in dignity in a viable global environment. It also calls for the preservation of the world economy, and proposes a more powerful authority under the United Nations' system to protect the earth's atmosphere. The Declaration accepts the principle of economic sanction, with control exercised by the International Court of Justice, and the principle of fair compensation. $^{16}$

The most recent event in the environmental movement was the United Nations Conference on Environment and Development (UNCED), which took place in Rio de Janeiro, Brazil, in June 1992 bringing together heads of states and governments from all over the world. The aim of the Conference was to find a common basis for action to protect the future of the earth and to secure for all inhabitants a more sustainable and more equitable future.

UNCED produced three non-binding international instruments: the Rio Declaration on Environment and Development, a non-legally binding Authoritative Statement of Principles for a Global Consensus on the Management, Conservation, and Sustainable Development of All Types of Forests, and the Agenda 21. The two binding international agreements were the Convention on Biological Diversity and the UN Framework Convention on Climate Change.

Principles 3 and 4 of the Rio Declaration constitute a compromise between developmental and environmental needs by affirming the right to development (Principle 3) and, at the same time, providing for environmental protection to achieve sustainable development (Principle 4). UNCED made a significant contribution to the development of international

14 ASEAN Agreement on the Conservation of Nature and Natural Resources, Art. 16.

15 Additional Protocol to the American Convention on Human Rights in the Areas of Economic, Social and Cultural Rights, International Legal Materials, Vol. 28, 1989, p. 165.

16 Declaration of the Hague on Environment, Intemational Legal Materials, Vol. 28, 1989, pp. 13081309. 
law, Principle 27 opening new chapter by referring to "international law in the field of sustainable development". ${ }^{17}$

All these international declarations and resolutions reflect the emerging social value of a clean environment for all. The right to a clean environment has been internationally recognized, which is the first step towards achieving the goals of environmental protectionism, in that, by recognizing the right to a clean environment, limitations are put on domestic political decisions of individual states. The right to a clean environment must also be reflected in the constitutions and laws of individual states to restrain the exercise of power and establish agreed norms of public conduct. In the following, we will look in more detail at two states, India and Tanzania.

\section{The right to a clean environment under the Indian Constitution}

This chapter intends to examine the implementation of the right to a clean environment in the Indian constitution, and to determine its efficiency in providing adequate protection to the environment through public interest litigation. India is the seventh largest nation in the world, and the second most populous state with a population of about 850 million people. India has large agricultural regions and is widely endowed with natural resources, such as forests, minerals and energy resources.

Being a member of the United Nations and having ratified the Universal Declaration of Human Rights, India took the human rights concept into consideration when drafting its Constitution during the years 1946-1949. The Preamble of the Constitution, which was adopted and enacted on 26 November 1949, secures social, economic and political justice, as well as freedom of expression, belief, faith and worship, and equality of status and opportunity. ${ }^{18}$ Article 253 of the Indian Constitution empowers the parliament to make laws for implementing any treaty, agreement or convention made with any other country at international conferences. Article 51(c) obliges the Indian government to foster respect for international law and treaty obligations. The Indian state as a federal system with 22 states. Most of the powers are in the hands of the central government. These include defence, foreign affairs, and interstate commerce. Article 246 of the Constitution deals with the subject matter of the laws made by parliament and by the legislature of the states. There are three lists which give exclusive powers to make laws to the union (Union List), to the states (State List), and to union and states (Concurrent List). ${ }^{19}$

17

18

United Nations Conference on Environment and Development, A/Conf.151/5.

R.S. Pathak, Human Rights and the Development of the Environment Law in India, Commonwealth Law Bulletin, Vol. 14, 1988, p. 1175.

See: Jain S. / Jain, V. (eds.), in: D.D. Khetrapal, Environmental Laws in India, 1984, pp. 4-5. 
India, honouring its international obligations on environmental issue, amended its Constitution in 1986. The Amendment Act called for the obligatory duty of the state and every citizen to protect and improve the environment. The most important parts of the Constitution which are of relevance here are Part III and Part IV. Part III of the Constitution enumerates a Bill of Rights within Article 12 to Article 32. Article 13 of Part III provides that any laws which are inconsistent with the Constitution are void. Article 14 states that everybody is equal before the law and has equal protection by the law. Article 21 provides that no person shall be deprived of his life or personal liberty except according to procedures established by the law. In the case of Francis Mullen $\mathbf{v}$ Union of India, it was observed by the court that the right to life enshrined in Article 21 includes the right to live with human dignity and to en joy the basic necessities of life. ${ }^{20}$ Any form of environmental pollution and spoilation could be regarded as violations of Article 21 of the Constitution. The High Court has explicitly ruled that Article 21 can be interpreted to include the right to a wholesome environment. This right is enforceable through writ jurisdiction in the nature of habeas corpus, certiorari, mandamus, prohibition, and quo warranto, under Article 32 before the Supreme Court and Article 226 before the High Court. Under these Articles the citizens have the right to petition the court to enforce their right.

Part IV of the Constitution specifies the Directive Principles of State Policy of India. Article 39 requires the state to direct its policy towards "securing the right to adequate means of livelihood for its citizens ... distribution of ownership and control of the national resources of the community so as best to subserve the common good, protection against abuse of health and strength of workers..., and that children are given opportunities and facilities to develop in a healthy manner and inconditions of freedom and dignity". Section A of Article 39 provides for free legal aid to all citizens. Article 47 of the Constitution provides for the improvement of public health as one of the primary duties of the state. Article 19 contains one of the fundamental rights safeguarding freedom of speech, association, and assembly, the right to move and reside within the territories of India, and the right to practice and trade in any profession.

Article 48A provides that "the state shall endeavour to protect and improve the environment and to safeguard forest and wildlife of the country". ${ }^{21}$ Article $51 \mathrm{~A}(\mathrm{~g})$ in Part IV of the Constitution deals with the fundamental rights and duties of the Indian people with regard to the environment. The Article provides that it "shall be the duty of every citizen of India to protect and improve the natural environment including forests, lakes, rivers and wildlife, and to have compassion for living creatures". ${ }^{22}$ The directive principles and

20

21

22
AIR (1981) SC 746.

F. Zohra Krentin, Economic and Social Council: Commission on Human Rights, Progress Report on Human Rights and Environment, 1992, p. 25.

Ibid. 
fundamental rights are complementary, and both Articles 48A and 51 A emphasize environmental protection and conservation policy within the frame work of the Constitutional Law of India. But Article 37 states explicitly that the principles of Part IV are not enforceable in court. It affirms though that they are nonetheless fundamental to the governance of the country, and the article imposes an obligation of the states to comply with these principles when making laws. Part III of the Indian Constitution is taken to accord individual rights which can be enforced through Article 32. An individual can not plead within Part IV of the Constitution as Article 37 does not allow it. The substantive rights which are protected by Part III entail certain minimum social and economic rights which flow from Part IV. It is, however, stated that the court will take cognizance of the interests protected by Part IV when deciding the scope, value and meaning of the rights contained within Part III. Part III of the Constitution confers rights directly upon the individual, Part IV determines precisely what the meaning of these rights is and which rights are important to be taken into consideration.

Despite all these constitutional provisions with regard to the right to a clean environment, India's pollution control system is weak because industry remained either reluctant to control pollution or beyond the reach of the law. The most drastic illustration of this failure was the escape of methylisocyanate gas from a Union Carbide pesticide plant in Bhopal in December 1984. The disaster cost about 2,500 lives with other people dying from the effects several years later. This incident showed that the regulations on pollution standards and chemical safety were inadequate as well as the government's disaster response system, and the system which allows people to live so close to industrial plants. It also showed that multinational corporations could operate plants at standards of safety below those in more developed countries. ${ }^{23}$

Apart from the inadequacies of laws, the inefficiency of legislation may be explained in part by the tension between Union and State authority, enforcement problems, the slow pace of the legislative process, as well as the lack of a private right of action and the inadequate representation of the interests of citizens in the legislative process compared to the industrial interests. ${ }^{24}$

The emergence of public interest litigation in India relaxed the rules of standing to allow concerned individuals or groups sufficient grounds to address the court. In the Gupta v Union of India case ${ }^{25}$, for example, the court found it difficult to enforce Part IV of the Indian Constitution because of Article 37. Nonetheless, it was shown by the court that the

J. McCormick, supra note 7, p. 161.

K. Ramakrishna, The Emergence of Environmental Law in the Developing Countries: A Case Study of India, Ecology Law Quarterly, Vol. 12, 1985, pp. 907-935.

Gupta v. Union of India case, AIR 1982 SC 149. 
provisions under Part III of the Constitution could be used to protect individual rights. The Gupta case pointed out the importance of Article 32 of the Constitution which allows any member of the public to act on the bonafide of the aggrieved person whose rights have been vindicated because of his social disadvantage or disability. Article 32(1) states that the Supreme Court can be moved to enforce the fundamental rights by any appropriate person. Article 21, for example, which protects life and liberty, can be enforced directly by an individual under Article 32. An individual can also enforce environmental matters under public interest litigation. In the case of Rural Litigation and Entitlement Kendra $\mathbf{v}$ State of Uttar Pradesh ${ }^{26}$, two writ petitions, brought before the Supreme Court under Article 32 and $51 \mathrm{~A}(\mathrm{~g})$ of the Constitution as public interest cases, sought the Court's help in abating the pollution caused by limestone quarries in the Mussoorie Hills of the Himalayas. The Court appointed several inspecting committees and, based on their reports, ordered the closing down of several mines. In its reasoning, the Court maintained that the preservation of the environment and to keep the ecological balance unaffected is a task not only governments but every citizen must undertake as this is the social obligation of every citizen, his fundamental duty as enshrined in $\operatorname{Article~} 51 \mathrm{~A}(\mathrm{~g})$ of the Constitution. That was the first time the right to clean environment found its expression in the Indian justice system.

In the case of Abilash Textile v Rajkot Municipal Corporation ${ }^{27}$, the Corporation issued a notice to Abilash Textile to desist in using the premises to discharge effluent onto the public road within a certain time of the factory would have to be closed. Abilash Textile put forward an argument that because it conducts business in the local community and gives employment to the people, the closing of the factory would affect their livelihood. Further, they argued that the notice which was issued to them did not afford them the opportunity to be heard which amounted to a violation of natural justice. But the question was whether there is any right to carry on business or trade in an unregulated manner causing nuisance to the public and a health hazard to the society at large. Article 19(6) states that everyone has the right to carry on business or trade, but it is subject to reasonable restrictions when the place of the business is not regulated in the interest of the public. The provision regarding fundamental duties of the citizens contained in Article $51 \mathrm{~A}(\mathrm{~g})$ of the Constitution enjoins upon all citizens the duty to protect and improve the natural environment. There is no way the textile factory owner would be protecting the natural environment by discharging effluents from the factory to the public road and public drainage. Article $51 \mathrm{~A}(\mathrm{~g})$ of the Constitution puts clear restriction on the fundamental right to carry on trade or business. One could also argue that if Article 21 talks about the right to livelihood, then the closure of the textile factory will affect the standard of living of the workers. The Supreme Court held that restrictions placed on the fundamental

27 Abilash Textile v Rajkot Municipal Corporation, AIR 1988 Guj. 
right to carry on trade or business are in the interest of the general public and constitutionally valid and not citizen can claim an absolute right to carry on business without complying with the restrictions placed on this behalf. ${ }^{28}$

In the case Damodhar Rao ${ }^{29}$, the Andhra Pradesh High Court prohibited the government from constructing residential houses on a piece of land previously allocated for a recreational park. In the proceedings, judge J. Choudary emphasised the need to develop India's environmental law by linking the issue of environmental protection with the right to life and personal liberty enshrined in Article 21 of the Constitution. ${ }^{30}$

Articles 226 and 14 also provide for public interest litigation involving matters concerning health. In the Janki Nathubahai Chhara case ${ }^{31}$, public litigants petitioned to the High Court about the poor hygienic condition of their community. The area became submerged during the monsoon season, and epidemics were spread in the whole area. In its verdict, the High Court persuaded the municipality and the state government to provide the area with a permanent sewerage and drainage system.

In the MCMehta $v$ Union of India cases ${ }^{32}$, an action was brought to court by the petitioners under Article 32 of the Constitution as public interest litigation in connection with the pollution of the river Ganges. There existed statutory provisions to prevent the pollution but there was no enforcement instrument. The continued discharge of effluents or toxic substances into the river was causing nuisances to the area. The petitioners were activists who were concerned about the health and the livelihood of those living in the area around the Ganges. The reasoning in that case linked the petitioners claim to Article 21 of the Constitution vis à vis with Article 48A and Article 51A which give effect to the enforcement of environmental protection. Article 21 which protects the right to livelihood can be enforced directly by an individual under Article 32. In the Mehta cases, the pollution of the river was dangerous for the inhabitants using the river. In that case, the court enforced Article 21 taking into account Articles 48A and $51 \mathrm{~A}(\mathrm{~g})$. The Supreme Court laid down strict conditions to control corporations engaged in the hazardous production of toxic substances and the rules of absolute liability, and directed the government to enforce standards required under the law. The Supreme Court asserted the importance of Article $48 \mathrm{~A}$ and $51 \mathrm{~A}(\mathrm{~g})$ of the Constitution. This case proved that collective rights could be

C.M. Abraham, The Indian Judiciary and Development of Environmental Law, South Asia Research, Vol. 11, 1991, p. 65.

31 Janki Nathubhai Chhara and another, Petitioners v Sardarnagar Municipality Sardar and another, Respondents, 73 AIR 1986 Gujarat 49.

32 M C Mehta v Union of India, AIR 1988 SC 1037. 
enforced through Article 21 linked with Articles $48 \mathrm{~A}$ and $51 \mathrm{~A}(\mathrm{~g})$. In the Mehta case it was pointed out that, apart from supplying water, the Ganges river is also of religious importance to the people living in the area. The social action group fighting on behalf of the community interpreted Article 25(1) which provides for the right to profess, practice, and propagate religion, linking it to $48 \mathrm{~A}$ and $51 \mathrm{~A}(\mathrm{~g})$ to establish their claim.

In the Mukti Sangharsh Movement v State of Maharashtra case ${ }^{33}$, the petitioners complained about an indiscriminate commercial extraction of sand from the Yerala river bed leading to the desertification of about thirty-eight thousand hectares of land in the valley destroying the ecological balance of the area. This case was brought to court by the social action group who were interested in environmental protection and safeguarding the local ecology. In most cases the petitioners seek the enforcement of statutory environmental law.

\section{The right to a clean environment in Tanzania}

This chapter deals with environmental problems in Tanzania, and evaluates the basic measures relevant to the right to a clean environment under the Tanzanian Constitution. Like many other less-developed countries, Tanzania has serious environmental problems. Tanzania has a land mass of $945,050 \mathrm{sqkm}$, with a population of 23 million. The coastline of the Western Indian Ocean forming the marine environment is about $800 \mathrm{~km}$ long, and the population there is about $3,147,344 .^{34}$

The country is characterised by a great diversity of climatic and physical conditions, mirrored in the human population which ranges from nomadic pastoralists to permanent cultivators. Large parts of Tanzania are arid and semi-arid areas, but also hilly slopes are affected by deforestation and prey to environmental problems caused by mankind. This exerts increasing pressure on the available natural resources. It was not until the population growth in the 19th century, that the people became aware of the environmental problems. But it was considered by the majority of the people as a political issue, and so they ignored it.

There are serious environmental problems confronting Tanzania: droughts, soil erosion, deforestation, poaching, infections and waterborne diseases, bush fires and refuse dumpings. There is also the problem of water pollution, particularly along the coast. Most settlers in both urban and rural areas cannot afford modern energy sources or fuel, and so

33 Supranote 18, p. 1178.

34 Costa R. Mahalu, Environmental Degradation and the Law in Tanzania, Verfassung und Recht in Übersee, Vol. 22, 1989, p. 461. 
most of them go to the forests, cut trees and burn them for charcoal as a source of energy and fuel. The consequence is depletion of the forest and the creation of environmental problems such as soil erosion, extermination of wild birds, and destruction of plants used in traditional medicine.

The government, seeing the extent of the environmental degradation and the effect on the natural resources of the country, called for the amendment of the Constitution in 1984 to give protection to the environment. The 1984 Constitutional Amendment Act 9(1)(C) provides that the authority of the state and all its instruments must direct all their activities and policies towards the task of ensuring that the affairs of the government are carried out in such a way as to ensure that the natural resources of the nation are developed, preserved, and utilized for the benefit of all citizens. This constitutional provision forms part of the Directive Principles of state policy which can be found in Part II of Chapter 1 of the Constitution consisting of Articles 6 to 11. Section 2, para. 27(1) of the 1984 amendment indicates that everyone has the responsibility of conserving the natural resources of the United Republic, property under the care of the state and all properties under the jurisdiction of the public, and also to respect the property of others. ${ }^{35}$ Unlike the Indian Constitution where the environmental rights are clearly stated, the Constitution of Tanzania does not spell out environmental provisions. The Indian courts have been able to link State Directive Principles which contain environmental provisions with the fundamental right to pass judgement in favour of environmental issues.

Although the Tanzanian Constitution establishes fundamental rights, it lacks judicial application in the protection of the environment. Even though Article 9(1)(F) of the Amendment calls on the maintenance and upholding of the dignity of man through full compliance with the provisions of the Universal Declaration of Human Rights, its enforcement is difficult, the legal and statutory provisions are rather too general and do not impose direct obligations or liabilities to guarantee a clean environment. For example, it is categorically stated in Article 7(2) that no court shall have power to determine any issue or question as to whether any action or omission by any person or authority, or as to whether any legislation or any decision is in conformity with the provisions of Part II of the Constitution. Part III of the Constitution provides for basic rights and duties. It could, therefore, be argued that the right to life provided in Article 14 guarantees every person the right to life, and subject to law, to the protection of his life by the society. Environmental degradation in the society will affect the right to life, and therefore focus must be based on Article 14 linking it with Articles 9(1)(c) and 27(1) to protect their right to a clean environment following the example of India Constitution. 
It was pointed out by Mwaikusa ${ }^{36}$ that in recent years Dar-es-Salaam City Council has had acute problems with the task of refuse collection and disposal, a duty assigned to the council under the Local Government (Urban Authorities) Act $1982^{37}$. An example is that of the village in Tanzania called Tabata situated West of a major dumping site. As the population of the village grew and the area developed into a residential area, the people felt the effect of the environmental damage caused by the dumping site which had been created by the City Council. Flies and other insects coming from the dumping site invaded homes, the waste burning polluted the air. In 1988, the residents of Tabata decided to go to court and fight for their right to a clean and healthy environment. They were led by Joseph Kessy and a dozen of others who filed a representative suit in the High Court at Dar-es-Salaam, which was registered as Civil Case No. 299/1988. The case was decided in favour of the Tabata residents in September 1989, and one of the orders issued against the City Council was a mandatory injunction requiring them to move from the site and take the necessary steps to identify and use another waste dumping site which would not be a nuisance or otherwise harmful to any residents. But the City Council applied to the court for the execution of that order to be stayed, in order to give the Council time to make necessary arrangements and preparations for an alternative site. This application was granted, and the City Council was given two years to make the necessary arrangements and preparations. During the two years, the Council was allowed to continue using the site. After the two years the Council filed another application for an extension, but this time the High Court rejected the application. ${ }^{38}$ The City Council moved to a different site called Mbagala to create a dumping site. The residents there mobilised themselves against the City Council to desist from using the area as a dumping site. The City Council moved to Kunduchi where the people insisted to maintain their right to a clean environment. The Kunduchi residents agreed as co-applicants on 31st October 1991 to file judicial review 795 in the High Court registry at Dar-es-Salaam as miscellaneous civil court No 90/1991. The decision of the Court prohibited the Dar-es-Salaam City Council to continue to carry out its decision of using Kunduchi as a refuse dumping site. The Court issued an order of mandamus and directed the City Council to discharge its function properly and in accordance with the law by establishing an appropriate refuse dumping site. ${ }^{39}$

In urban and rural areas, local authorities have a duty to ensure a clean and healthy environment. But this they do not always fulfil due to a number of reasons, including lack of funds, unlike in India where authorities face public interest litigation groups who use various techniques, such as advocacy, fighting with the people to lie their claim to the

J. Timothy Mwaikua, The problem of refuse dumping in the city of Dar-es-Salaam, 1993, pp. 1-5 (unpublished) 
courts and giving them free legal aid to enforce their right to a clean environment. In Tanzania, the residents do not always find it easy to take legal action against the local authorities on environmental issues. Although Tanzania has a legal aid committee set up by the Faculty of Law at the University in 1960, the aims of this committee are limited to teaching purposes. The cases that the committee has taken up are in defence of social groups such as workers, tenants, women, children and peasants, but not in defence of environmental rights ${ }^{40}$ like the public litigation groups in India.

Mahalu $^{41}$ pointed out that the mining activities taking place on the coast are having a disastrous effect on the environment. The extraction of coral limestones, for instance, at Wazo Hill for the production of cement causes atmospheric pollution.

The government, realising the mounting environmental problems in Tanzania, decided to bring to a halt the damaging effects on natural resources. It legislated the Fisheries Act of 1970. The Fisheries (explosions, poisons and water pollution) Regulations of 1982 prohibit the use of dynamite fishing. This legislation thus also regulates environmental protection. $^{42}$

The land environment has its legislation controlling pollution, for example, the Natural Resources Ordinance Cap 259. This ordinance provides for the improvement of the natural resources of the country including soil and waters. The ordinance makes it a punishable offence to negligently divert or injure any soil or water conservation work. But the ordinance does not outline conservation or improvement measures to be promoted or observed in relation to the natural resources. ${ }^{43}$

In 1977, the Water Utilization (Control and Regulation) Act was promulgated. The Act provides that all water in Tanzania is vested in the United Republic. It gives the people the right to use water for any purpose as long as they do not pollute water and cause injury to public health, livestock, fish or crops. Any one who violates this Act will face penalty in form of a cash fine or imprisonment. ${ }^{44}$ The Act, however, does not go far enough to be enforced to protect the environment. In 1981, this Act was amended, and a central water board was established whose functions are to research and investigate on pollution. The

40

See for legal committee in Tanzania: Contradictory developments in teaching and practice of Human Rights in Tanzania, in: S.F.R. Coldham /J. Hatchard / P.E. Slinn (eds.), Journal of African Law, p. 119.

41

42

Supra note 34.

43

Supra note 34, p. 467.

Ibid., p. 466.

44 Water Utilization (Control and Regulation) Act 1977, S.2, in: Costa R. Mahalu, supra note 34, p. 446. 
board has the power to formulate steps and direct the government in respect to pollution control. The board has an advisory role and can enforce pollution control.

In 1983, the government legislated for the establishment of a National Environmental Management Council with the National Environment Management Act No. 19 of 1983. The Council's task is to formulate policies on the environment and act as an advisory body to the government on all matters relating to the environment. The Council operates closely with the National Land Planning Commission. ${ }^{45}$ Through this Council, the government has succeeded in ensuring that hazardous wastes and radioactive substances are not imported from abroad to be dumped in Tanzania.

Mahalu $^{46}$ pointed out that it is difficult to implement some environmental legislation in Tanzania, for example, in the mining sector, which is an area were the state earns its foreign currency. Apart from that, the state lacks institutional enforcement regulations. The National Environmental Council is merely recommendatory in function. It is also not well financed to carry out its duties properly. The Pollution Control Regulations are not in themselves sufficient to ensure a clean environment. ${ }^{47}$ Tanzania environmental law is based on constitutional provisions which are lengthy and unclear, and also unenforceable. As a result, Tanzania has not developed a significant body of case law and of the complete lack of public interest litigation. It is hoped that Tanzanian authorities will follow the trail blazed by India, relying to a greater degree on judicial developments.

\section{Conclusions}

Chapter 1 pointed out the general problems of the right to a clean environment. In chapter 2, we examined the international recognition of the right to clean environment, and evaluated the content and character of legal obligations concerning the right to clean environment. It was shown that all these international declarations and resolutions, although not binding on the states, become justiciable if international declarations are enacted in national constitutions. In chapter 3, it was demonstrated that under the Indian Constitution the right to clean environment is clearly stated, in particular in their constitutional amendments $48 \mathrm{~A}$ and $51 \mathrm{~A}(\mathrm{~g})$. It was shown that the directive principles and fundamental rights under the Constitution are treated as complementary. The judiciary interprets these articles in protecting the environment. The Indian legal system emphasizes the importance of environmental law. Having said that, there are still many problems as to how to solve the pollution problems. Chapter 4 has shown that the Tanzanian Constitution does not spell out environmental provisions as clearly as the Indian Constitution.

Supra note 34.

Mahalu, supra note 34 . 
The legal provisions in Article 9(1)(c) of the Tanzanian Constitution, which reflect on the environment, form part of the directive principles of state policy. But these provisions are not justiciable. In Tanzania, the people's fundamental right to bring to court cases of environmental importance is not guaranteed. But still, they have a spirit of mobilisation to exert pressure on the government and the authorities, and fight for their right to a clean environment. We, therefore, pointed out that Tanzania adopts the constitutional approach of India to enforce environmental statutory law.

Overall, the evidence presented in this essay argues for the adoption of more effective methods of enforcement of the provisions of various environmental laws in India and Tanzania. Although the Indian environmental law is more developed than the Tanzania, the two countries have similar problems, which are: (1) lack of government finance to use to enforce the legal provisions on the protection of the environment, (2) lack of a proper data base to determine the environmental problems, (3) lack of money to purchase equipment for environmental use, and (4) economic obstacles, such as the need to exploit the wild life and natural resources for the livelihood of the local people. Many developing countries are embarking on projects which are vital for their economic development but detrimental to the environment.

In the light of the foregoing issues, it is suggested that the governments of the two countries should take the following measures: The governments should set up public funds from the tax revenues from industrials to use to clean up environmental disasters. National priorities should be set out listing those areas that need to be cleaned up. We also argue for the establishment of constitutional remedies which give powers to the courts to issue writs in the nature of habeas corpus, mandamus, prohibition, que warranto, certiorari, directions and orders to enforce fundamental rights. The international community must set up monitoring forces to see whether governments who have ratified the International Declaration on Right to Clean Environment have added this right to their national constitutions. The fundamental right to clean environment must be guaranteed in every constitution and must be justiciable. It is also important for the people to participate in the decision making process and to have the right to recourse to legal actions before competent administrative and judicial organs. The people must have the right to first-hand information on environmental matters. Every proposal which has an environmental impact should be accompanied by an environmental impact statement, and should be published and open for public scrutiny. In order to realize the right to clean environment, governments must create a regulatory framework to monitor and control environmental standards. To summarize, the establishment of the right to a clean environment is an expression of individual and societal values to an ecologically sound environment and a sustainable management of natural resources. Unless this right is enshrined in the national constitutions, the state power is under no real obligation to enact and enforce laws that protect the environment. 
whereby a democratic-elected legislature can act legally to draw up a „final“ constitution in accordance to the 34 constitutional principles in Schedule 4 of the actual Constitution. This same legislature and the executive drawn from its ranks is entitled by law to govern for a period of five years, even though a final constitution should have been agreed on after only two years.

\section{The Right to Clean Environment: Lessons from India and Tanzania}

\section{By Emmanuel Opoku Awuku}

The need for environmental protection has brought about the international recognition of the right to a clean environment expressed in various international declarations and resolutions. In order to implement the right to a clean environment, it must be reflected in national constitutions and laws of individual states. India and Tanzania serve as examples here for an analysis of the problems in implementing and enforcing the right to a clean environment.

Ratifying international agreements on environmental issues, India included the right to clean environment in ist constitution. It is clearly stated in the Directive Principles. The states of India have to comply with these Directive Principles when making laws. The Directive Principles are, however, not enforceable in court. Various case studies show that the right to a clean environment can be enforced by linking it, for example, with the right to life enshrined in the Indian constitution. The importance of public interest litigation groups is shown.

The constitution of Tanzania does not state the right to a clean environment. It contains, however, some environmental provisions. But these are too general and very difficult to enforce.

Despite the environmental provisions in the constitutions of both India and Tanzania, the laws remain inadequate and the difficulties in enforcing them persist and with it the environmental problems. 